\title{
Physicochemical and Sensory Properties of Cookies Produced from Brown Rice and Fermented Afzelia Africana Flour Blends
}

\author{
Moses T. Ukeyima Bibiana D. Igbabul* Ochefije S. Peter \\ Department of Food Science and Technology, University of Agriculture, Makurdi, Nigeria \\ Correspondence: Bibiana D. Igbabul, Department of Food Science and Technology, University of Agriculture, \\ Makurdi, Nigeria
}

\begin{abstract}
Cookies were produced from brown rice and fermented Afzelia Africana flour blends and their physicochemical and sensory properties were determined. Five flour formulation, designated as samples A,B,C,D and E were produced. Sample A was control (100\% wheat), while sample B,C,D and E were brown rice and fermented Afzelia Africana flour in the ratios 95:5, 90:10, 85:15, and 80:20 percentage respectively. The result of the proximate composition showed that there was a significant increase at $\mathrm{p}<0.05$ in protein, fat, fibre, ash and moisture content. The value ranged from $8.15 \%-16.92 \%, 9.20 \%-10.06 \%, 1.25 \%-4.13 \%, 21.42 \%-25.95 \%, 1.06 \%-3.07 \%$ respectively. The physical property revealed the diameter, thickness, spread ratio and weight, ranged as; $4.33 \mathrm{~cm}-$ $4.46 \mathrm{~cm}, 2.50 \mathrm{~cm}-2.00 \mathrm{~cm}, 17.32-22.30$ and $13.40 \mathrm{~g}-10.40 \mathrm{~g}$, respectively. The mineral content of calcium, phosphorus, potassium, and manganese increased at $\mathrm{p}<0.05$ in the range $13.67 \mathrm{mg} / 100 \mathrm{~g}-24.17 \mathrm{mg} / 100 \mathrm{~g}$, $33.27 \mathrm{mg} / 100 \mathrm{~g}-61.85 \mathrm{mg} / 100 \mathrm{~g}, 56.47 \mathrm{mg} / 100 \mathrm{~g}-322.42 \mathrm{mg} / 100 \mathrm{~g}$ and $56.44 \mathrm{mg} / 100 \mathrm{~g}-67.19 \mathrm{mg} / 100 \mathrm{~g}$ respectively. The beta carotene and vitamin $C$ contents increased at $\mathrm{p}<0.05$ in the range $1.57 \mathrm{mg} / 100 \mathrm{~g}-2.04 \mathrm{mg} / 100 \mathrm{~g}$ and $0.01 \mathrm{mg} / 100 \mathrm{~g}-2.15 \mathrm{mg} / 100 \mathrm{~g}$ respectively. The sensory scores showed that cookies produced from the brown rice and fermented Afzelia Africana flours all compared favourably with cookies from $100 \%$ wheat flour and therefore acceptable nutrient dense cookies could be successfully prepared from the composite flour of brown rice and fermented Afzelia Africana flour.
\end{abstract}

Keywords: Brown rice, fermented Afzelia Africana, cookies, composite flour, wheat

DOI: $10.7176 /$ FSQM/88-05

Publication date:July $31^{\text {st }} 2019$

\section{Introduction}

Cookies are one of the confectionary food products consumed in Nigeria especially among children. It is a ready to eat, convenient and inexpensive food product, containing digestive and dietary principles of vital importance according to (Oyeyinka et al., 2014). They are popular snacks widely consumed all over the world by people of all ages (Okpala et al., 2013). Cookies hold an important position in snack food industry due to variety in taste, crispiness and digestibility. Cookies are made in variety of style using an array of ingredients including sugars, spices, chocolates, butter, peanut butter, nut or dried fruits according to (Vijayakumar et al., 2013)

Afzelia Africana also called Mahogany bean is an underutilized legume plant in the family of fabaceae sub family Caesalpiniaceae. It has been reported that the seeds contain about $27.04 \%$ proteins, $31.71 \%$ crude fat, $33.09 \%$ total carbohydrates and 5.28\% moisture, Igbabul et al., (2014). It is known by different names in Nigeria. It is called "yiase"; among the Tivs,, "akparata" among the Ibos and "apa" "ukpo" "kawa" among the Yoruba's, Idomas and the Hausa people of Nigeria respectively (Igbabul et al., 2014)

Researchers have reported that Afzelia Africana is a good source of protein as well as a soluble dietary fibre (Odenigbo 2004). Soluble dietary fibre has beneficial effects on blood glucose and lipid levels in diabetes mellitus, it lowers blood pressure and serum cholesterol (Anderson et al, 1999). Afzelia Africana provides protection against colon cancer, obesity and cardiovascular diseases according to (Ubom, 2007).

Apata and Akubor, (1997) reported that Afzelia Africana (Mahogany bean) has relatively high quantities of phosphorus, zinc, iron and exceptionally high calcium. Legumes however, contain a variety of toxic constituents as well as anti-nutritional factors such oxalate, saponin, haemoglutin, trypsin, phytates, tannin, protease inhibitor and goitrogen. Hence the need for fermentation.Fermented Afzelia Africana seed flour has been reported to contain decreased anti-nutrients, improved nutritional value (Igbabul et al 2014).

Rice, a major commodity in world trade, provides $20 \%$ of the world's dietary energy supply (FAO, 2006). Rice contains approximately $7.3 \%$ protein, $2.2 \%$ fat, $64.3 \%$ available carbohydrates, $0.8 \%$ fibre and $1.4 \%$ ash content (Zhou et al., 2002). Rice is reported to have hypoallergenic properties due to the absence of gliadin (Gujral et al., 2004).

Brown unpolished rice would be used due to its high nutrients content (Pankaj, 2008). Composite flour refers to the mixture of different concentrations of non-wheat flour from cereals, legumes, roots and tubers with wheat flour or can be a mixture of flours other than wheat flour (Okpala et al 2011). Again Ubbor and Akobundu (2009) also reported that composite flours are recently manufactured not only to improve the desired functional properties of end product but also to improve nutritional composition which result to better balance in essential amino acid, 
thus, higher protein quality. Composite flour has several advantages in developing countries including the reduction of wheat flour importation and promotion of high-yielding native plant species by (Hasmadi et al., 2014).

The adoption of these locally produced flours in the bakery industry will increase the utilization of indigenous crops cultivated in Nigeria and also lower the cost of bakery products (Ayo et al., 2002).

There are several composite cookies readily available and investigated (Eke-Ejiofor et al 2015), but there is little information on the use of brown rice and fermented Afzelia africana flour blends. Therefore, fermented Afzelia africana, and brown rice flour would be used in this study to produce cookies and analysis of its physicochemical and sensory properties would be carried out.

\section{Materials and Methods}

\subsection{Source of Raw Materials}

Afzelia africana seed was obtained from a local market in Makurdi and the brown rice was obtained from MIKAP Nigeria Limited, producer of MIVA rice. Other equipment and reagent of analytical grade was obtained from the Food processing laboratory of Federal University of Agriculture.

\subsection{Preparation of Raw Materials}

\subsubsection{Preparation of Fermented Afzelia africana Flour}

Afzelia africana (mahogany bean) seeds was purchased from a local market and brought to the Food Chemistry Laboratory. About $4 \mathrm{~kg}$ of the Afzelia africana seed was sorted out and de-Capped, winnowed and cleaned to dislodge dust, foreign matter, stones, broken and defective seeds according to Igbabul et al., (2014). The seeds were roasted for 3-5minutes to aid de-hulling. The de-hulled seeds were fermented naturally at 72 hours, oven dried and milled into flour using the attrition mill and sieved using a $1.0 \mathrm{~mm}$ sieve.

\subsubsection{Preparation of Brown Rice Flour}

According to Yeh (2004) brown rice grains was bought from Mikap producer of Miva rice. Rice was soaked for $4-5 \mathrm{hrs}$ for at $30 \%$, then grinded in excess water and dried at $40 \mathrm{OC}$ overnight, grinded and sieved with $1.0 \mathrm{~mm}$ size to obtain fine flour using BSZ Pin mill. Flour samples were packaged in polyethylene bags and stored at $4{ }^{\circ} \mathrm{C}$ before use.

\subsection{Formulationof composite flours}

The fermented Afzelia Africana and Brown Rice flours were sieved using 1.0mm mesh sieve to obtain uniform particle size and then mixed in the proportions shown in Table 1. The proportions were based on preliminary work. Mixing was achieved with the use of Kenwood mixer at speed 6 for 3 min to obtain uniform blending.

\subsection{Preparation of Cookies}

The cookies were baked using the method of (Ceserani et al., 2008). The ratio of ingredient used for the preparation of cookies is shown in Table 2. Fat and sugar were creamed to a smooth consistency, and eggs were added and mix. The dry ingredients; flour, baking powder and salt was mixed together and added to cream followed by vanilla flavour and nutmeg and mix to dough. The dough was kneaded to a uniform thickness and cut into different shapes. They were placed in green pans that were egg washed. The cookies were baked at $150 \mathrm{OC}$ for $20 \mathrm{~min}$. The cookies were stored in a plastic container with lid in a refrigerator at $4 \mathrm{OC}$ prior to analysis.

\subsection{Analyses}

\subsubsection{Determination of Proximate Composition of Cookies}

The protein, fat, crude fibre, ash, moisture contents were determined using the method (AOAC, 2005), while the carbohydrate was determined by difference using the method of (Egounlety, 2001), by subtracting the total sum of the percentage of fat, moisture, ash, crude fibre, and protein content from hundred (100). The gross energy values were estimated by multiplying the values of crude protein, fat and carbohydrate by their respective physiological fuel value of 4,9 and 4 respectively.

\subsubsection{Determination of Physical Properties of Cookies}

Cookies diameter (D) and thickness (T) were determined using vernier callipers, while cookies weight was determined using an electronic weighing balance (Mettler PE160 Balance, Switzerland). Spread ratio was expressed as diameter/thickness (D/T) (McWatters et al., 2003). The average values of 2 replicate determinations were reported.

2.5.3 Determination of minerals and vitamin content of the cookies. This was carried out using the AOAC (2005) with the aid of Atomic Absorption Spectrophotometer (AA 800 Perkin Elmer Germany). 2.5.4 Determination of Sensory Properties of Cookies

Twenty-four hours after preparation of the cookies, sensory evaluation was carried out. A total of 15 panellists who were familiar with the quality attributes of the cookies were recruited from staff and students of the Department of Food Science and Technology. Each panellist evaluated all the samples prepared for each treatment 
in one session. Criteria for selection of panellists was that panellists were regular consumers of cookies and not allergic to any cookies. Panellists were instructed to evaluate appearance, flavour, texture, crispness, and general acceptability of the cookies. A nine-point Hedonic scale was used with1=dislike extremely, 5=neither like nor dislike, and 9=like extremely (Ihekoronye \& Ngoddy, 1985). Samples were identified with three-digit code numbers and presented to panellists. The panellists were instructed to rinse their mouths with water after every sample. They were also asked to comment freely on samples on the questionnaires given to them.

\subsection{Statistical Analysis}

The data obtained from the work and sensory evaluation was subjected statistically to analysis of variance (ANOVA) and means were separated using Tukey's test. (Steele \& Torrie, 1980). The least significance difference was used in determining significant differences between the means and separation of the means where significant differences existed at P, 0.05, using SPSS package version 16.0.

\section{Result and Discussion}

3.1 Proximate Composition of Cookies Produced Brown Rice and Fermented Afzelia Africana Flour Blends The result of this study showed that the proximate composition of cookies varied significantly as shown in Table 3 . These variations were a function of the different composition of the samples. The moisture content of the samples which ranged from $9.20 \%$ to $10.06 \%$, this may be due to the consistency of baking temperature and time, since it was the same baking condition that was used for all. The value obtained from the determination of protein value of the cookies of Brown rice and fermented Afzelia Africana ranges from $8.15 \%$ to $16.92 \%$ with the least being sample A (control) and showed significant difference at $(\mathrm{P}<0.05)$. This increase in protein value could be attributed to increase in microbial mass during fermentation causing extensive hydrolysis of the protein molecules to amino acids and other simple peptide (Igbabul et al., 2014). These protein content values are comparable with the values of 6.83-16.6\% reported by (Chinma and Gernah, 2007) on cookies from composite flour of wheat, mango and soybeans. Also comparable with the value of $10.44 \%-14.73 \%$ reported by (Igbabul et al., 2015) on cookies from composite flour of wheat cocoyam and African yam beans. Increase in crude fat ranges from $21.42 \%$ to $25.95 \%$ and showed significant different in all samples. This increase in fat could be a result of extensive breakdown of large molecules of fat into simple fatty acids (Igbabul et al., 2014). These increase in fat is however higher than the range of value of 18.12-20\% reported by Ebere et al., (2015) on wheat flour, cashew, and apple residue as source of fibre in cookies production. The value obtained from the determination of dietary fibre showed an increase with no significant different at $(\mathrm{P}<0.05)$ of sample A and $\mathrm{B}$. The increase in dietary fibre in Brown rice and fermented Afzelia Africana flour in cookies production shows that it would provide dietary fibre that would offer protection against cardiovascular diseases, obesity and colon cancer and promote the effective functioning of the human digestive tract (Igbabul et al., 2014). This observation is lower than that reported by Ebere et al., (2015) but of health benefit since it falls within the range of high fibre cookies as reported by Lerrea et al., (2005) and Camire et al., (2007). The crude fibre is also in agreement with the recommendation of (FAO/WHO, 1994) that fibre content should not be more than $5 \mathrm{~g}$ dietary fibre per $100 \mathrm{~g}$ dry matter of all cookies and that would enhance gastro intestinal tract and cardiovascular health. Ash content ranging from $1.06 \%$ to $3.07 \%$ shows that cookies produced from Brown rice and fermented Afzelia Africana will be rich in nutrient due to low ash content which may be due to leaching of soluble minerals into the processing water during fermentation period (Igbabul et al., 2014). Low ash content had earlier been reported for snacks made from Afzelia Africana seed flour (Onyechi et al., 2013). The ash content value are comparable with the values of 1.6-2.6\% reported by Ebere et al., (2015). The observation in moisture content is in agreement with the report of Smith (1972) who established that moisture content of cookies should not exceed 14\%. Okaka (2009) also reported low moisture for cookies. Carbohydrate content ranges from 58.92 - 39.87 Brown rice and fermented Afzelia Africana while the enegy value ranges from $473.07 \mathrm{kcal}-460.71 \mathrm{kcal}$ Brown rice and fermented Afzelia Africana.

Table 1: Formation of Composite Flour for Cookies Production

\begin{tabular}{lccc}
\hline Samples & Wheat $(\%)$ & Brown Rice flour $(\%)$ & Fermented Afzelia africana flour $(\%)$ \\
\hline A (CONTROL) & 100 & 0 & 0 \\
B & 95 & 5 \\
C & 90 & 10 \\
D & 85 & 15 \\
E & 80 & 20 \\
\hline
\end{tabular}


Table 2. Quantity of Ingredients for Cookies Production

\begin{tabular}{lcc}
\hline Ingredients & Percentage $(\% \mathrm{w} / \mathrm{w})$ & Amount $(\mathrm{g})$ \\
\hline Vegetable fat & 22.7 & 50 \\
Suger (granulated) & 18.8 & 40 \\
Nutmeg & 0.2 & 0.3 \\
Vanilla flavour (liquid) & 0.1 & $5.0 \mathrm{ml}$ \\
Egg (whole, fresh) & 7 & $30 \mathrm{ml}$ \\
Salt & 0.4 & 1 \\
Baking powder & 14.6 & 2 \\
\hline
\end{tabular}

Source: (Ceserani et al, 2008).

Table 3: Proximate Composition of cookies from Brown Rice and Fermented Afzelia Africana Flour Blends

\begin{tabular}{|c|c|c|c|c|c|c|c|c|c|}
\hline \multirow[t]{2}{*}{ Sample } & \multirow[b]{2}{*}{ Protein } & \multicolumn{8}{|c|}{ Composition (\%) } \\
\hline & & Moisture & Ash & Fat & $\begin{array}{l}\text { Crude } \\
\text { Fibre }\end{array}$ & & $\mathrm{CHO}$ & & E.V (kcal) \\
\hline A & $\begin{array}{l}8.15 \mathrm{e} \\
\pm 0.04\end{array}$ & $9.20 \mathrm{c} \pm 0.05$ & $1.06 \mathrm{~d} \pm 0.03$ & $21.42 \mathrm{e} \pm 0.04$ & $\begin{array}{l}1.25 \mathrm{~d} \\
0.04\end{array}$ & \pm & $\begin{array}{l}58.92 \mathrm{a} \\
0.04\end{array}$ & \pm & $\begin{array}{l}461.06 \mathrm{~d} \\
\pm 0.02\end{array}$ \\
\hline B & $\begin{array}{l}12.27 \mathrm{~d} \pm \\
0.08\end{array}$ & $8.95 \mathrm{~d} \pm 0.02$ & $1.26 \mathrm{c} \pm 0.04$ & $23.28 \mathrm{~d} \pm 0.01$ & $\begin{array}{l}1.29 \mathrm{~d} \\
0.08\end{array}$ & \pm & $\begin{array}{l}52.95 b \\
0.03\end{array}$ & \pm & $470.40 \mathrm{~b} \pm 0.02$ \\
\hline $\mathrm{C}$ & $\begin{array}{l}13.96 \mathrm{c} \\
\pm 0.01\end{array}$ & $10.96 \mathrm{a} \pm 0.04$ & $1.36 \mathrm{c} \pm 0.04$ & $24.15 \mathrm{c} \pm 0.03$ & $\begin{array}{l}2.38 \mathrm{c} \\
0.01\end{array}$ & \pm & $\begin{array}{l}47.19 c \\
0.02\end{array}$ & \pm & $461.95 \mathrm{c} \pm 0.01$ \\
\hline $\mathrm{D}$ & $\begin{array}{l}15.11 \mathrm{~b} \\
\pm 0.03\end{array}$ & $9.31 \mathrm{c} \pm 0.01$ & $2.32 \mathrm{~b} \pm 0.01$ & $25.09 \mathrm{~b} \pm 0.00$ & $\begin{array}{l}3.40 \mathrm{~b} \\
0.04\end{array}$ & \pm & $\begin{array}{l}44.77 d \\
0.25\end{array}$ & \pm & $473.07 \mathrm{a} \pm 0.03$ \\
\hline $\mathrm{E}$ & $\begin{array}{l}16.92 \mathrm{a} \\
\pm 0.01\end{array}$ & $10.06 \mathrm{~b} \pm 0.04$ & $3.07 \mathrm{a} \pm 0.04$ & $25.95 \mathrm{a} \pm 0.05$ & $\begin{array}{l}4.13 \mathrm{a} \\
0.01\end{array}$ & \pm & $\begin{array}{l}39.87 \mathrm{e} \\
0.01\end{array}$ & \pm & $460.71 \mathrm{e} \pm 0.01$ \\
\hline LSD & 0.11 & 0.11 & 0.10 & 0.06 & 0.10 & & 0.44 & & 1.25 \\
\hline
\end{tabular}

*Values are means of \pm standard deviations of duplicate determination

*Means within the same column with different superscripts are significantly different $(\mathrm{P}<0.05)$

A $($ Control $)=100 \%$ Wheat

$\mathrm{B}=95 \%$ Brown rice flour, $5 \%$ Fermented Afzelia Africana

$\mathrm{C}=90 \%$ Brown rice flour, $10 \%$ Fermented Afzelia Africana

$\mathrm{D}=85 \%$ Brown rice flour, $15 \%$ Fermented Afzelia Africana

$\mathrm{E}=80 \%$ Brown rice flour , 20\% Fermented Afzelia Africana

E.V $=$ Energy value

L.S.D $=$ Least Significant Difference

Table 4: Physical Properties of Cookies Produced from Brown Rice and Fermented Afzelia Africana Flour Blends.

\begin{tabular}{ccccc}
\hline Sample & Diameter $(\mathbf{c m})$ & Thickness $\mathbf{( c m})$ & Spread Ratio & Weight $(\mathbf{g})$ \\
\hline $\mathbf{A}$ & $4.33 \mathrm{e} \pm 0.00$ & $2.50 \mathrm{a} \pm 0.01$ & $17.32 \mathrm{e} \pm 0.07$ & $13.40 \mathrm{a} \pm 0.01$ \\
$\mathbf{B}$ & $4.93 \mathrm{a} \pm 0.01$ & $2.27 \mathrm{~b} \pm 0.01$ & $21.72 \mathrm{~d} \pm 0.07$ & $13.20 \mathrm{~b} \pm 0.01$ \\
$\mathbf{C}$ & $4.67 \mathrm{~b} \pm 0.01$ & $2.13 \mathrm{c} \pm 0.20$ & $21.92 \mathrm{c} \pm 0.07$ & $13.00 \mathrm{c} \pm 0.57$ \\
$\mathbf{D}$ & $4.60 \mathrm{c} \pm 0.01$ & $2.00 \mathrm{~d} \pm 0.01$ & $23.00 \mathrm{a} \pm 0.07$ & $12.20 \mathrm{~d} \pm 0.01$ \\
E & $4.46 \mathrm{~d} \pm 0.01$ & $2.00 \mathrm{~d} \pm 0.21$ & $22.30 \mathrm{~b} \pm 0.07$ & $10.40 \mathrm{e} \pm 0.01$ \\
LSD & 0.02 & 0.01 & 0.06 & 0.03 \\
\hline
\end{tabular}

\footnotetext{
*Values are means of \pm standard deviations of duplicate determination

A $($ Control $)=100 \%$ Wheat

$\mathrm{B}=95 \%$ Brown rice flour, $5 \%$ Fermented Afzelia Africana

$\mathrm{C}=90 \%$ Brown rice flour, $10 \%$ Fermented Afzelia Africana

$\mathrm{D}=85 \%$ Brown rice flour, $15 \%$ Fermented Afzelia Africana

$\mathrm{E}=80 \%$ Brown rice flour , 20\% Fermented Afzelia Africana

L.S.D $=$ Least Significant Difference
}

*Means within the same column with different superscripts are significantly different $(\mathrm{P}<0.05)$ 
Table 5: Mineral Composition of Cookies Produced from Brown Rice and Fermented Afzelia Africana Flour

\begin{tabular}{ccccc}
\hline Sample & \multicolumn{4}{c}{ Composition (mg/100g) } \\
\hline A & Calcium & Phosphorus & Potassium & Manganese \\
B & $13.67 \mathrm{e} \pm 8.09$ & $33.27 \mathrm{~d} \pm 0.01$ & $56.47 \mathrm{e} \pm 0.34$ & $56.44 \mathrm{~d} \pm 0.77$ \\
C & $19.23 \mathrm{~d} \pm 0.03$ & $43.40 \mathrm{c} \pm 0.07$ & $125.90 \mathrm{~d} \pm 0.67$ & $57.13 \mathrm{~d} \pm 0.04$ \\
D & $21.22 \mathrm{c} \pm 0.04$ & $50.27 \mathrm{~b} \pm 0.01$ & $201.01 \mathrm{c} \pm 0.01$ & $59.22 \mathrm{c} \pm 0.07$ \\
E & $23.15 \mathrm{~b} \pm 0.04$ & $57.99 \mathrm{a} \pm 2.70$ & $298.40 \mathrm{~b} \pm 0.03$ & $63.18 \mathrm{~b} \pm 0.10$ \\
LSD & $24.17 \mathrm{a} \pm 0.06$ & $61.85 \mathrm{a} \pm 0.74$ & $322.42 \mathrm{a} \pm 1.41$ & $67.19 \mathrm{a} \pm 0.03$ \\
\hline
\end{tabular}

*Values are means of \pm standard deviations of duplicate determination

*Means within the same column with different superscripts are significantly different $(\mathrm{P}<0.05)$

A $($ Control $)=100 \%$ Wheat

$\mathrm{B}=95 \%$ Brown rice flour, 5\% Fermented Afzelia Africana

$\mathrm{C}=90 \%$ Brown rice flour, 10\% Fermented Afzelia Africana

$\mathrm{D}=85 \%$ Brown rice flour, $15 \%$ Fermented Afzelia Africana

$\mathrm{E}=80 \%$ Brown rice flour , 20\% Fermented Afzelia Africana

L.S.D $=$ Least Significant Difference

Table 6: Vitamin Composition of Cookies Produced from Brown Rice and Fermented Afzelia Africana Flour Blends

\begin{tabular}{ccc}
\hline Sample & Composition $\mathbf{( m g / 1 0 0 g )}$ & \\
\hline A & Beta-carotene & Vitamin C \\
B & $1.57 \mathrm{c} \pm 0.03$ & $0.01 \mathrm{e} \pm 0.01$ \\
C & $1.64 \mathrm{c} \pm 0.01$ & $0.20 \mathrm{~d} \pm 0.00$ \\
D & $1.78 \mathrm{~b} \pm 0.01$ & $0.35 \mathrm{c} \pm 0.01$ \\
E & $1.97 \mathrm{a} \pm 0.01$ & $1.17 \mathrm{~b} \pm 0.01$ \\
LSD & $2.04 \mathrm{a} \pm 0.01$ & $2.15 \mathrm{a} \pm 0.02$ \\
\hline
\end{tabular}

*Values are means of \pm standard deviations of duplicate determination

*Means within the same column with different superscripts are significantly different $(\mathrm{P}<0.05)$

A $($ Control $)=100 \%$ Wheat

$\mathrm{B}=95 \%$ Brown rice flour, $5 \%$ Fermented Afzelia Africana

$\mathrm{C}=90 \%$ Brown rice flour, $10 \%$ Fermented Afzelia Africana

$\mathrm{D}=85 \%$ Brown rice flour, $15 \%$ Fermented Afzelia Africana

$\mathrm{E}=80 \%$ Brown rice flour , 20\% Fermented Afzelia Africana

L.S.D $=$ Least Significant Difference

Table 7: Sensory Scores of Cookies Produced from Brown Rice and Fermented Afzelia Africana Flour

\begin{tabular}{cclllll}
\hline Sample & & \multicolumn{5}{c}{ Sensory Attributes } \\
\hline & Appearance & Aroma & Crispness & Taste & Texture & General Acceptability \\
A & $7.53 \mathrm{a} \pm 0.92$ & $7.67 \mathrm{a} \pm 0.72$ & $6.73 \mathrm{a} \pm 1.67$ & $8.00 \mathrm{a} \pm 1.20$ & $7.40 \mathrm{a} \pm 0.99$ & $8.00 \mathrm{a} \pm 0.76$ \\
$\mathbf{B}$ & $6.80 \mathrm{ab} \pm 0.78$ & $6.40 \mathrm{~b} \pm 1.45$ & $7.07 \mathrm{a} \pm 1.28$ & $7.27 \mathrm{a} \pm 1.44$ & $6.87 \mathrm{ab} \pm 1.13$ & $7.87 \mathrm{a} \pm 0.86$ \\
$\mathbf{C}$ & $5.73 \mathrm{~b} \pm 1.39$ & $5.40 \mathrm{~b} \pm 1.84$ & $6.67 \mathrm{a} \pm 1.18$ & $6.07 \mathrm{~b} \pm 1.22$ & $6.53 \mathrm{ab} \pm 1.06$ & $6.40 \mathrm{~b} \pm 1.30$ \\
$\mathbf{D}$ & $6.53 \mathrm{ab} \pm 1.60$ & $5.93 \mathrm{~b} \pm 1.39$ & $6.47 \mathrm{a} \pm 1.16$ & $6.60 \mathrm{~b} \pm 1.50$ & $6.60 \mathrm{ab} \pm 1.12$ & $6.80 \mathrm{~b} \pm 1.08$ \\
E & $6.53 \mathrm{ab} \pm 1.85$ & $6.40 \mathrm{~b} \pm 1.12$ & $6.73 \mathrm{a} \pm 1.44$ & $6.53 \mathrm{~b} \pm 0.92$ & $6.80 \mathrm{ab} \pm 0.86$ & $6.80 \mathrm{~b} \pm 1.06$ \\
LSD & 0.78 & 0.90 & 0.94 & 0.81 & 0.61 & 0.58 \\
\hline
\end{tabular}

*Values are means of \pm standard deviations of duplicate determination

*Means within the same column with different superscripts are significantly different $(\mathrm{P}<0.05)$

A $($ Control $)=100 \%$ Wheat

$\mathrm{B}=95 \%$ Brown rice flour, $5 \%$ Fermented Afzelia Africana

$\mathrm{C}=90 \%$ Brown rice flour, $10 \%$ Fermented Afzelia Africana

$\mathrm{D}=85 \%$ Brown rice flour, $15 \%$ Fermented Afzelia Africana

$\mathrm{E}=80 \%$ Brown rice flour , 20\% Fermented Afzelia Africana

L.S.D $=$ Least Significant Difference

\subsection{Physical Properties of Cookies Produced From Brown Rice and Fermented Afzelia Africana Flour Blends}

The result of physical properties of cookies produced from Brown rice and fermented Afzelia Africana flour blends 
is presented in Table 4; the diameter of cookies gradually decreases with addition of fermented Afzelia Africana flour. The lowest diameter was recorded in cookies from sample A (control). This could be explained on the basis of increase in hydrophilic starch granules of fermented Afzelia Africana flour leading to moisture absorption and increase diameter of cookies. The thickness of cookies from sample A (control) flour were significantly different $(\mathrm{P}<0.05)$ from the cookies made from composite flours of rice and fermented Afzelia Africana and decrease with addition of rice and fermented Afzelia Africana flour, while weight of cookies decreases with the lowest been 13.40 of sample A (control). Spread ratio of cookies increased with the lowest being sample A of 17.32 and highest of being sample $\mathrm{E}$ of 22.30. The physical characteristics of cookies diameter, thickness, spread ratio and weight showed that there were significant difference $(\mathrm{P}<0.05)$ in all the samples. This could be as a result of the ability of insoluble fibre to absorb water up to 15 times its own weight and swelling up in size, causing variation in the diameter, thickness and spread factor as reported by Ogunjobi et al., (2010), Ogunwolu et al., (2010) and Oyewole et al.,(1996). The diameter, spread ratio and weight value is lower than that of $18.01 \mathrm{~cm}, 15.16-11.78$, and 18.0120.15 respectively, and higher than $0.45-0.55 \mathrm{~cm}$ in thickness reported by Igbabul et al., (2015). The diameter, spread ratio, and weight value is higher than that of 3.00-3.02 cm, 6.25-6.04, and 2.91g-3.31g respectively, reported by Ebere et al., (2015).

\subsection{Mineral Composition of Cookies Produced From Brown Rice and Fermented Afzelia Africana Flour Blends}

The mineral content of cookies prepared from Brown rice and fermented Afzelia Africana flour blend is presented in Table 5. Minerals such as calcium, phosphorus, potassium, Manganese ranges from $13.67 \mathrm{mg} / 100 \mathrm{~g}$ to $24.17 \mathrm{mg} / 100 \mathrm{~g}, 33.27 \mathrm{mg} / 100 \mathrm{~g}$ to $61.85 \mathrm{mg} / 100 \mathrm{~g}, 56.47 \mathrm{mg} / 100 \mathrm{~g}$ to $322.42 \mathrm{mg} / 100 \mathrm{~g}$ and $56.44 \mathrm{mg} / 100 \mathrm{~g}$ to $67.19 \mathrm{mg} / 100 \mathrm{~g}$ respectively. Calcium, phosphorus, potassium and Manganese content of cookies were significantly $(\mathrm{P}<0.05)$ higher than $100 \%$ wheat (control) cookies. The increase in addition of Brown rice and fermented Afzelia Africana flour increase the mineral content of cookies. Deficiency of certain minerals like calcium, phosphorus has been shown to aggravate carbohydrate intolerance (Franz et al., 2002). This reult agrees to Adebayo et al., (2013) about the high content of minerals such as of potassium, phosphorus, and calcium present in Afzelia Africana and Pankaj (2008) of manganese present in brown rice.

\subsection{Vitamin Composition of Cookies Produced From Brown Rice and Fermented Afzelia Africana Flour Blends}

The vitamin content of cookies prepared from Brown rice and fermented Afzelia Africana flour blend is presented in Table 6. Vitamin such as beta carotene (Vitamin A) ranges from $1.57 \mathrm{mg} / 100 \mathrm{~g}$ to $2.04 \mathrm{mg} / 100 \mathrm{~g}$ while that of vitamin $C$ ranges from 0.01 to $2.15 \mathrm{mg} / 100 \mathrm{~g}$. Beta carotene and vitamin $\mathrm{C}$ content of cookies were significantly at $(\mathrm{P}<0.05)$ higher than $100 \%$ wheat (control) cookies. The beta carotene and vitamin $\mathrm{C}$ content increased with increase in the substitution of fermented Afzelia Africana which is a good source of beta carotene and vitamin $\mathrm{C}$ as reported by Emmanuel et al., (2011). The result of high vitamin A agrees with Onyechi et al., (2013) who reported high vitamin A content of snack made from Africana africana seed and vitamin $\mathrm{C}$ present in Afzelia Africana as reported by Egwuje et al., (2015).

\subsection{Sensory Scores of Cookies Produced From Brown Rice and Fermented Afzelia Africana Flour Blends}

The result in sensory attribute is shown in Table 7: for appearance, there was a significant difference at $(\mathrm{P}<0.05)$ in sample A, B and C but no significant different in sample D and E. The difference observed in appearance was as a result of the roasting of fermented Afzelia Africana during preparation which increases its crude protein and minerals such as potassium, calcium, manganese, and phosphorus (Adebayo 2013). There was significant difference in the aroma of sample A (control) due to different flours used in preparing cookies. There was no significant different in the crispness of the cookies. This implies that the crispness of cookies that served as control (Sample A) and other samples (B, C, D and E) had no difference in consumer preference. Taste of sample A and B had no significant difference. This also implies that the taste of cookies which served as control (Sample A) and other samples (B, C, D and E) also had no difference in consumer preference but was significantly different in sample C, D and E. Texture of sample A as rated by the panelist is 7.40 and that of sample B, C, D and E to be $6.87,6.53,6.60$ and 6.80 respectively. This implies that the texture of the cookies which served as control (Sample A) and other sample (B, C, D, E) were liked moderately.

\section{Conclusion}

Cookies with increased protein, fibre, ash, vitamins and minerals contents were produced successfully using composite flour of brown rice and fermented Afzelia africana flour blends.

The cookies made with the flour blends of brown rice and fermented Afzelia Africana compared favourably with the cookies produced from $100 \%$ wheat flour. Therefore its use for the production of cookies and other confectionaries will go a long way in alleviating malnutrition, hunger and also reduce dependence on wheat flour 
and its importation. This will lead to savings in foreign exchange and enhance farmers income.

\section{References}

Adekalu, T.B.; Ojuawo, R.O. and Adekalu, O.A. (2011).Proximate and elemental analysis of banana (Musaparadisiaca) during ripening process. Nigeria Food Journal 29 (1) 29 -35.

Anderson J. Allgppd. L. Turner, J.Oelrgen, P. and Daggy, B.P (1999). American Journal of Clinical Nutrition 70(4) 466-473.

Akpata, M.I. and Akubor, P.I. (1999) Chemical Composition and Selected Functional Properties of Sweet Orange (Citrus sinensis) Seed Flour. Plant Foods for Human Nutrition 54, 353-362

Aworh, O.C (2008). The Role of Traditional Food Processing Technologies in National Development: the West African Experience. International Union of Food Science \& Technology.

Ayo JA, Gaffa T (2002) Effect of undefatted soybean flour on the protein content and sensory quality of 'KunnuZaki' Nigeria Food Journal 20: 7-9.

AOAC. (1990). Official methods of analysis of the Association of Official Analytical Chemists. 15th edition. Washington, DC, Association of Official Analytical Chemists.

Adebayo, S.F., Ojo, O.C., (2013). Nutrient compostion and functional properties of Afzelia Africana seeds.IOSR Journal of Environmental Science, Toxicology and Food Technology, 6(5), 01-03.

Balami et al., (2004) Y.A. Balami, P.T. Bolaji, F. Hamza, E.J. Bahago, G. Komolafe, S.C. Onyeiwu, A. Hassan

Chinma, C. E., Igbabul, B. D. and Omotayo, O. O.(2012) Quality Characteristics of cookies prepared from unripe plantain and defatted sesame flour Blends. American Journal of Food technology7(7): 398-408.

Chinma, C. E., \& Gernah, D. I. (2007). Physicochemical and sensory properties of cookies produced from cassava/soyabean/mango composite flours. Journal of Food Technology, 5, 256-260.

Ceserani, V., and Kinton, R. (2008). Practical Cookery (10th ed.), John Wiley and Sons, New York.

Camire, M.E., Douggherty, M.P. and Briggs, J.L. (2007). Functionality of fruit powder in extruded common breakfast cereals. Food Chemistry, 101(2):765-770.

Eke-Ejiofor, J. (2015). Physico-chemical and pasting properties of starches fromcassava, sweet potato and threeleaf-yam and their application in salad cream production. International Journal of Biotechnology and Food Science, 3(2), 23-30.

Egwujeh, S.I.D and Yusufu, P,A. (2015). Chemical Composition of Aril Cap of African Oak (Afzelia Africana) seed. European Journal of Food Science and Technology. No.3,;41-47.

Emmanuel, T.F.; Omale, J; Olajide, J.E. and Utu -Baku, A.B. (2011). Variation in micro -nutrient content and lipid profile of some avian eggs. American journal of experimental Agriculture. 1(4) $343-352$.

Franz MJ, Bantle J, Beebe CA, Brunzell JD, Chiasson JL, Garg A, Holzmeister LA, Hoogwerf B, Mayer-Davis E, Mooradian A, Purnell JQ, Wheeler M (2002). American Diabetes Association Position Statement: Evidence-based nutrition principles and recommendations for the treatment and prevention of diabetes and related complications. Journal of American Dietary Association;102: 109-118

FAO/WHO. (1994). Codex Alimentarius: foods for special dietary uses(including foods for infants and children). (2nd ed.). Food Agricultural Organisation, Rome.

Gujral, H.S and Rosell, C.M. (2004) Functionality of rice flour modified with a microbial transglutaminase. Journal of Cereal Science. 39: 225-230.

Hasmadi, M., Siti Faridah, A., Salwa, I., Matanjun, P., Abdul Hamid, M. and Rameli, A. S. (2014). The effect of seaweed composite flour on the textural properties of dough and bread. Journal of Applied Phycology 26:1057-1062.

Igbabul, B. D.,Amove,J.and Okoh, A.(2014a). Quality evaluation of composite bread produced from wheat, defatted soy and banana flours. International Journal of Nutrition and Food science. 3(5): 471-476.

Igbabul, Bibiana D. Benbella M. Iorliam and Etietop N. Umana (2015). Physicochemical and Sensory Properties of Cookies Produced From Composite Flours of Wheat, Cocoyam and African Yam Beans. Journal of Food Research. 4: 2

Ihekoronye AI, Ngoddy PO. London: Macmillan; (1985). Integrated food science and technology for the tropics.

Iwe, M.O., (2002). Handbook of Sensory Methods and Analysis. Rojoint Communication Services Ltd., Enugu, Nigeria

Lerrea, M.A., Chang, Y.K. and Martnez-Bustosc, (2005). Some functional properties of extruded orange pulp and its effect on the quality of cookies. LWT-Food Science and Technology, 38:213-220.

Man S, Păucean A, Muste S, Pop A (2014). Studies on the formulation and quality characteristics of gluten free muffins. Journal of Agro-alimentary Processes and Technologies. 20(2): 122-127.

McWatters, K. H., Ouedraogo, J. B. A., Resurreccion, V. A., Hung, Y., \& Phillips, R. D.(2003). Physical and sensory characteristics of sugar cookies containing mixtures of wheat, fonio (Digitaria exilis) and cowpea (Vigna unguiculata) flours. International Journal of Food Science and Technology, 38, 403-410.

Odenigbo, U.M. Obizoba, I.C. (2004). Journal of Biomedical Investigation 2(2); 86-91. 
Onyechi, A.U.; Ibeanu, V.N.; Eme, P, Eze, O and Ossai, C. (2013). Nutrient and phytochemical composition of formulated diabetic snacks made from two Nigerian foods Afzelia Africana and Detariummicrocarpium seed flour. Pakistan Journal of Nutrition. 12(2): 108 -113.

Oyeyinka SA, Oyeyinka AT, Karim OR, Toyeeb KA, Olatunde SJ, et al (2014) Biscuit making potentials of flours from wheat and plantain at different stages of ripeness. Croatian Journal of Food Science and Technology. 6: $36-42$.

Okpala, L., Okoli, E. and Udensi, E. (2013) Physico-chemical and sensory properties of cookies made from blends of germinated pigeon pea, fermented sorghum and cocoyam flours. Food Science and Nutrition. 1: 8-14.

Onwuka, G.I. Onwuka (2005) Food analysis Napthali Print, Lagos Nigeria.

Pankaj (2008) Brown rice is healthier white rice. Times of India, December 25, 2014 Google Scholar

Steel, R. G. D., and Torrie, J. H. (1980). Principles and Procedures of Statistics. 2nd ed. New York:McGraw-Hill.

Yeh, A. I (2004). Preparation and application of rice In: Champagne, E. T. ed. Rice: Chemistry and Tecnology, 3rd edn. St Paul, MN: American Association of Cereal Chemists, pp, 495-540.

Vijayakumar and Priya, Mayakrishnan, K \& T. Nancy, F \& Abdullah, Noorlidah \& Ahmed, Bakrudeen (2013). Biosynthesis, Characterisation and Anti-Bacterial Effect of Plant-Mediated Silver Nanoparticles Using Artemisia nilagirica. Industrial Crops and Products, 41, 235-240.

Ubbor, S.C. and Akobundu,E.N.T. (2009). Quality Characteristics of Cookies from Composite Flours of Watermelon Seed, Cassava and Wheat. Pakistan Journal of Nutrition 8 (7): 1097-1102.

Ubom, D.E. (2007). Nutrition, health and our environment. Sendina Ltd, Nigeria. Pg 140.

Wei, C., Kwon, O. Y., Lui, X., Kim, H. C., Yoo, W. K., Kim, H. M. and Kim, M. R. (2007). Effect of aging on changes in rice. Protein pro詙les of major Korean rice cultivars. Journal of Food Science and Nutrition 12(2): 103-110.

Zhou, Z., Robards, K., Helliwell, S and Blanchard, C. (2002) Composition and functional properties of rice. International Journal of Food Science Technology, 37: 849-868. 